\title{
The Institutional and Cultural Context of Cross-National Variation in COVID-19 Outbreaks
}

\author{
Wolfgang Messner
}

University of South Carolina, 1014 Greene Street, Columbia, SC - 29208, USA

wolfgang.messner@moore.sc.edu

8 Background. The COVID-19 pandemic poses an unprecedented and cascading threat to the health and economic prosperity of the world's population.

10 Objectives. To understand whether the institutional and cultural context influences the COVID1119 outbreak.

12 Methods. At the ecological level, regression coefficients are examined to figure out contextual

13 variables influencing the pandemic's exponential growth rate across 96 countries.

14 Results. While a strong institutional context is negatively associated with the outbreak $(B=-0.55$

$15 \ldots-0.64, p<0.001)$, the pandemic's growth rate is steeper in countries with a quality education

$16 \operatorname{system}(\mathrm{B}=0.33, p<0.001)$. Countries with an older population are more affected $(\mathrm{B}=0.46, p<$

17 0.001). Societies with individualistic (rather than collectivistic) values experience a flatter rate of

18 pathogen proliferation $(\mathrm{B}=-0.31, p<0.001)$, similarly for higher levels of power distance $(\mathrm{B}=$

$19-0.32, p<0.001)$. Hedonistic values, that is seeking indulgence and not enduring restraints, are

20 positively related to the outbreak $(B=0.23, \mathrm{p}=0.001)$.

21 Conclusions. The results emphasize the need for public policy makers to pay close attention to

22 the institutional and cultural context in their respective countries when instigating measures aimed 23 at constricting the pandemic's growth.

Introduction

As of March 21, 2020, more than 271364 cases of coronavirus disease 2019 (COVID-19) were

27 confirmed worldwide. Italy, then the second most impacted country with 47021 confirmed cases, recorded its first three cases only on January $31,2020 .{ }^{1}$ Efforts to completely contain the new virus

29 largely failed. As a consequence of global mobility and trade, people carrying the virus arrive in 30 countries without ongoing transmission. Governments are currently scrambling to put in 
medRxiv preprint doi: https://doi.org/10.1101/2020.03.30.20047589; this version posted April 1, 2020. The copyright holder for this preprint

(which was not certified by peer review) is the author/funder, who has granted medRxiv a license to display the preprint in perpetuity. It is made available under a CC-BY-ND 4.0 International license .

Cross-National Variation in COVID-19 Outbreaks

Messner, W.

31 unprecedented measures to flatten the curve, because the faster the infection curve rises, the

32 quicker the national health care systems get overloaded beyond their capacity of treating people

33 effectively. While ultimately the same number of people are likely to get infected, reducing the

34 initial number of cases would make the outbreak easier to control overall. ${ }^{2}$

35 In this study, I examine cross-national variation in COVID-19 outbreaks in 96 countries to analyze

36 the impact of global connectivity, national institutions, socio-demographic characteristics, and

37 cultural values on the initial arc of the curve. While getting to know the epidemic through, inter

38 alia, mathematical models is important for national and international countermeasures, experience

39 from HIV shows that politics and ideology are often far more influential than evidence and best

40 practice guidance. ${ }^{3}$ It is well acknowledged that politics is central to policy-making in health

41 generally, and that the institutional and cultural context plays a defining role in health policy

42 outcomes. With the H1N1 2009 influenza pandemic, social determinants of health affected

43 outcomes beyond clinically recognized risk factors. ${ }^{4}$ Thus, getting to know the national context of

44 the COVID-19 pandemic will be essential in informing the development of evidence-based 45 measures.

$46 \quad$ Model and method

47 I implemented a linear regression model, in which the exponential growth rate of confirmed 48 COVID-19 cases is regressed on institutional, socio-demographic, and cultural variables 49 associated with testing and reporting cases, supporting the pathogen's path, and controlling the 50 outbreak. As of March 21, 2020, there is sufficient COVID-19 outbreak data to estimate the model 51 for 96 countries. All variables are detailed in Table 1. The aim of this ecological approach is to 52 study health in an environmental context. ${ }^{5}$

\section{Outbreak data}

54 In this study, I use data from the European Center for Disease Control and Prevention (ECDC),

55 which is an EU agency established in 2005 with the aim to strengthen Europe's defense against

56 infectious diseases. The ECDC collects and harmonizes data from around the world, thus providing

57 a global perspective on the evolving pandemic; the datafile is available via Our World in Data, an

58 effort by the University of Oxford and Global Change Data Lab. ${ }^{1}$ Note that the World Health

59 Organization (WHO) changed their cutoff time on March 18, 2020, and, due to overlaps, their data

60 is not suitable for understanding the pandemic's development over time beyond this date. ${ }^{1}$ To have 
medRxiv preprint doi: https://doi.org/10.1101/2020.03.30.20047589; this version posted April 1, 2020. The copyright holder for this preprint (which was not certified by peer review) is the author/funder, who has granted medRxiv a license to display the preprint in perpetuity. It is made available under a CC-BY-ND 4.0 International license.

Cross-National Variation in COVID-19 Outbreaks

Messner, W.

61 enough datapoints for estimating the relative growth rate (dependent variable GROWTH) in an

62 exponential population model, I only include countries which have reported their first case on or

63 before March 12, 2020, as per the ECDC dataset. With a change point analysis using the Fisher

64 discriminant ratio as a kernel function, I confirm that the first reporting date is in fact the start of

65 the outbreak. ${ }^{6}$ Accordingly, there are no later significant change points in the outbreak.

66 Testing and reporting cases

67 During the current COVID-19 outbreak, practically all countries are struggling to test every person 68 who should be tested from a medical standpoint. Under the guidelines of most countries, clinicians 69 will test suspected patients only if they have travelled to an epidemic region. ${ }^{7}$ The more tests a 70 country performs, the more confirmed cases it tends to have. Because data on the number of tests 71 performed is neither comparable across countries (it may refer to tests or individuals) nor updated 72 regularly, ${ }^{1}$ I introduce variables into the regression model, which could purportedly be associated 73 with a country's capability and commitment to test and report. First, I use a perception indicator 74 about the functioning of political institutions (independent variable POLINS; $0=$ widespread 75 irregularities to $4=$ perfectly fair) from the 2016 edition of the International Profiles Database 76 (IPD), which is a survey conducted by the French Directorate General of the Treasury. ${ }^{8}$ Second, I 77 calculate the time between Jan 01, 2020 (as a rather random starting point) and discovering the 78 first case (independent variable DISCOV). This time lag helps a country to learn from others' 79 experiences, and ramp up their own testing capabilities. As this is likely a non-linear effect, I

80 logarithmically transform this measure in the regression model.

81 Interconnectivity between populations

82 Because international connectivity between countries increases the potential spread of a pathogen, ${ }^{9}$

83 I introduce the independent variable IMPORT, which represents the value of all goods and other 84 market services received by a country from the rest of the world (year 2017; in bn USD; based on 85 data from the World Bank). ${ }^{10}$ Additionally, with the logged variable DNSITY, I capture a 86 country's population density, which is defined as all residents in a country divided by land area in 87 square kilometers (year 2018; data from the World Bank). ${ }^{11}$

88 Institutional context

89 Because strong stakeholder processes can bring benefits to accepting decisions being made by the 90 government, ${ }^{12,13}$ I use an indicator on participation of the population in political institutions from 91 the IPD database (independent variable PARPOP; $0=$ very low to $4=$ strong participation). ${ }^{8}$ 
medRxiv preprint doi: https://doi.org/10.1101/2020.03.30.20047589; this version posted April 1, 2020. The copyright holder for this preprint (which was not certified by peer review) is the author/funder, who has granted medRxiv a license to display the preprint in perpetuity. It is made available under a CC-BY-ND 4.0 International license .

Cross-National Variation in COVID-19 Outbreaks

Messner, W.

92 Second, the society's openness can be described by the freedom of access to foreign information

93 (independent variable FREEINF; $0=$ no to $4=$ total freedom; from IPD). ${ }^{8}$ Third, the functioning

94 of the public administration is, inter alia, mirrored in the level of corruption (independent variable

95 CORRUP; 0 = high to 4 = very low level of corruption; from IPD). ${ }^{8,14}$

96 Socio-demographic mapping

97 Variable EDUCAT is a logged indicator of an education system's performance, calculated as the 98 gross intake ratio to the last grade of primary education (average of years 2000 to 2018; data from 99 the World Bank). ${ }^{15}$ And as older people (especially in Italy) seem to get hit more frequently by 100 COVID-19, ${ }^{16}$ I introduce AGEMED as an independent variable for a country's median age 101 (current data from the CIA World Factbook). ${ }^{17}$

102 Cultural variables

103 Given that culture determines the values and behaviors of societal members, ${ }^{18}$ specific behavioral 104 manifestations of culture can influence the transmission of pathogens. ${ }^{19}$ Although country 105 boundaries are not strictly synonymous with cultural boundaries, there is abundant evidence that 106 geopolitical regions can serve as useful proxies for culture. ${ }^{19}$ Thus, I use scores from Hofstede's 107 dimensional framework of culture, ${ }^{18}$ available for 73 countries included in my analysis. 108 Individualism (independent variable INDLSM, score of 1 to 100) is defined as a preference for a 109 loosely-knit social framework, whereas collectivism (low scores on the same variable) represents 110 a preference for a tightly-knit framework, in which individuals expect members of a particular 111 ingroup to look after each other in exchange for unquestioning loyalty. Previous studies have 112 shown that the regional prevalence of pathogens is negatively associated with individualism. ${ }^{19}$ 113 Power distance (independent variable POWDIS, score of 1 to 100) expresses the degree to which 114 the less powerful members of a society accept and expect that power is distributed unequally, with 115 the fundamental issue being how societies handle inequalities among its members. Accordingly, 116 the norm in countries with high values of POWDIS is the belief that everyone should have a 117 defined place within the social order. The epidemiology of infections has been shown to be linked 118 to power distance, but results are not conclusive. ${ }^{20}$ In low power distance cultures, people are less 119 willing to accept directions from superiors, ${ }^{21}$ with potentially detrimental effects on controlling the 120 outbreak of a pandemic. Conversely, in consumer research, country-level high power distance 121 results in weaker perceptions of responsibility to aid others in a charitable way. ${ }^{22}$ Lastly, the 122 dimension of indulgence (independent variable INDULG, score of 1 to 100) reflects hedonistic 
medRxiv preprint doi: https://doi.org/10.1101/2020.03.30.20047589; this version posted April 1, 2020. The copyright holder for this preprint (which was not certified by peer review) is the author/funder, who has granted medRxiv a license to display the preprint in perpetuity. It is made available under a CC-BY-ND 4.0 International license.

Cross-National Variation in COVID-19 Outbreaks

Messner, W.

123 societies that allow people to enjoy life and have fun, as compared to societies where restraint is

124 emphasized. It can be assumed that countries scoring high on the indulgence dimension will have

125 more difficulty constraining social activity, implementing social distancing measures, and thereby

126 restricting its citizens' satisfying activities.

\section{Statistical results}

128 To test the association of the context variables on the growth rate of COVID-19, I use linear 129 regression with pairwise exclusion of missing values. The results suggest that a significant 130 proportion of the total variation of the outbreak can be explained by the context variables, $131 F(12,55)=26.16, p<0.001$. Multiple $R^{2}$ indicates that $85.09 \%$ of the variation in growth can be 132 predicted by the context variables; estimated power to predict multiple $R^{2}$ is at the maximum of 1331.000 , as calculated with $\mathrm{G}^{*}$ Power 3.1. Table 2 expounds the regression coefficients.

134 Multicollinearity in epidemiological studies can be a serious problem, being a result of 135 unrepresentative samples or insufficient information in samples, that is not enough countries or 136 omission of relevant variables. $^{23}$ I have conducted several diagnostics to eliminate 137 multicollinearity issues in the regression analysis. First, the VIF never exceeds 4 (see Table 2),

138 which is well below the recommended threshold of $\frac{1}{1-R^{2}}=6.70$. Second, the highest correlation 139 coefficient is 0.683 between variables DISCOV and IMPORT, which is below the typical cutoff 140 of 0.8 . Only another two correlation coefficients are above the 0.5 cutoff (EDUCAT and 141 AGEMED: -0.56; POLINS and FEEINF: -0.58). Third, the variance-decomposition matrix does 142 not show any groups of predictors with high values. In summary, a multicollinearity problem can 143 be excluded.

144 Further, I conduct several tests to assess the robustness of the results by including other contextual 145 variables. But because it is nearly impossible to establish a complete list of such confounding 146 variables, I additionally quantify the potential impact of unobserved confounds (Table 2, column 147 Impact threshold). ${ }^{24}$ For instance, the necessary impact of such a confound for the variable 148 DISCOV would be 0.80 , that is, to invalidate the inference that the time lag has on the growth rate, 149 a confounding variable would have to be correlated with both GROWTH and DISCOV at $\sqrt{0.80}=$ $150 \quad 0.89$, which is a strong correlation. Next, to alleviate concerns that the worldwide spread of the 151 virus is not yet fully known and that this study might have been conducted too early in the 152 pandemic, I ask how many countries would have to be replaced with unobserved cases for which 
medRxiv preprint doi: https://doi.org/10.1101/2020.03.30.20047589; this version posted April 1, 2020. The copyright holder for this preprint (which was not certified by peer review) is the author/funder, who has granted medRxiv a license to display the preprint in perpetuity. It is made available under a CC-BY-ND 4.0 International license .

Cross-National Variation in COVID-19 Outbreaks

Messner, W.

153 the null hypothesis is true (i.e., the contextual variables have no influence on the growth rate) in 154 order to invalidate the inference. ${ }^{25}$ As Table 2 (column Confound threshold) shows, about $86 \%$ of 155 the countries would have to be replaced with countries for which the effect is zero in order to 156 invalidate the influence of DISCOV. In summary, it can be claimed that the influence of the 157 identified contextual variables on the pandemic's growth rate is reasonably robust.

Discussion

159 As expected, countries with functioning political institutions (POLINS) report a higher relative 160 growth rate of the outbreak, probably due to a better testing and reporting infrastructure. Likewise, 161 for countries that have been hit by the outbreak at a later point of time (DISCOV). The scatterplot 162 in Figure 1 graphically depicts the relationship between discovery of the first case and the rate of 163 the outbreak. In this diagram every dot represents a country; Turkey shows up as an outlier having 164 reported their first case only on March $12,2020,{ }^{2}$ but showing a very rapid outbreak. International 165 connectivity as measured by a country's import volume (IMPORT) elevates the growth rate 166 (Figure 2). Contrary to expectations, population density (DNSITY) is negatively related to the 167 outbreak. Maybe people in densely populated countries are more likely to adhere to precautionary measures because they realize the danger of physical closeness to pathogen transmission? ${ }^{26}$ Or

169 does this indicate that social distancing measures are more effective in crowded places? Yet, the 170 DNSITY coefficient is not statistically significant in the regression model, and the confound 171 threshold is rather low ( $p=0.105$, confound threshold 17.28\%). A strong institutional context is 172 negatively associated with the outbreak, as measured by participation in political institutions 173 (PARPOP), access to foreign information (FREEINF), and absence of corruption (CORRUP).

174 Rather surprisingly and contrary to the experience with HIV, ${ }^{27}$ the quality of a country's education

175 system is positively associated with the outbreak. Do people believe that the pathogen affects only 176 poor countries, and therefore do not take precautionary measures seriously? Or do better educated 177 people test more due to increased awareness? Providing a conclusive reasoning at this point in the 178 COVID-19 outbreak is not possible, and I encourage further research in the months or years to 179 come.

180 Whilst potentially controversial, an association between cultural characteristics and the outbreak 181 of the pandemic should not be totally surprising, since implementing countermeasures is ultimately 182 behavioral science. ${ }^{28}$ The data shows that individualistic societies experience a lower outbreak 183 growth rate, which is in line with previous studies about pathogen proliferation. ${ }^{19}$ People in more 
medRxiv preprint doi: https://doi.org/10.1101/2020.03.30.20047589; this version posted April 1, 2020. The copyright holder for this preprint

(which was not certified by peer review) is the author/funder, who has granted medRxiv a license to display the preprint in perpetuity.

It is made available under a CC-BY-ND 4.0 International license .

Cross-National Variation in COVID-19 Outbreaks

Messner, W.

184 collectivistic cultures apparently find it more difficult to engage in social distancing practices. And

185 because the effectiveness of social distancing measures has rarely been assessed before, ${ }^{26}$ this calls

186 for a cross-cultural investigation in further research. Higher levels of power distance are associated

187 with a lesser growth rate of the outbreak; it appears that individuals in low power distance cultures

188 are less willing to blindly accept directions from the government on how to change their social

189 behavior. $^{21}$ Instead, they prefer a say in decisions affecting their lifestyle. Even though managing

190 individuals' obstinate behavior is quite a challenge in a pandemic, politicians in low-power

191 distance countries need to work more towards achieving a buy-in of their electorate. Lastly, a

192 country's hedonistic tendency towards indulgence and not accepting restraints is positively linked

193 to the outbreak.

194 My study indicates that governments need to tailor their strategies for combating the COVID-19

195 pandemic to the institutional and cultural context in their respective countries. In addition to system

196 change, culture change, that is, the establishment of new norms and behavior, is needed. ${ }^{28}$ This $^{2}$

197 change needs to be driven by leaders showing unequivocal and explicit support for outbreak

198 control policies and their implementation, hopefully bringing the outbreak under control and

199 reducing its overall magnitude. This is especially important because the unpredictable future of

200 the pandemic will be exacerbated by public's misunderstanding of health messages, ${ }^{29}$ causing not

201 only worry but likely also mental health issues in the population.

202

203 Conflict of interest

204 The author declares that there is no conflict of interest.

205

206

Human participant protection

207 No humans participated in this study. The data used for the regression model in this study is

208 available in its entirety in Table 1. The original data sources are referenced in the section Model 209 and methods. 
medRxiv preprint doi: https://doi.org/10.1101/2020.03.30.20047589; this version posted April 1, 2020. The copyright holder for this preprint (which was not certified by peer review) is the author/funder, who has granted medRxiv a license to display the preprint in perpetuity. It is made available under a CC-BY-ND 4.0 International license.

Cross-National Variation in COVID-19 Outbreaks

Messner, W.

\section{References}

212 1. Roser M, Ritchi H, Ortiz-Ospina E. Coronavirus disease (COVID-19) - Statistics and 213 research. OurWorldInData.org. https://ourworldindata.org/coronavirus. Published 2020. 214 Accessed March 21, 2020.

215 2. Hellewell J, Abbott S, Gimma A, et al. Feasibility of controlling COVID-19 outbreaks by isolation of cases and contacts. Lancet Glob Heal. 2020:488-496. doi:10.1016/s2214$109 x(20) 30074-7$

3. Buse K, Dickinson C, Sidibé M. HIV: Know your epidemic, act on its politics. JR Soc Med. 2008;101(12):572-573. doi:10.1258/jrsm.2008.08k036

4. Lowcock EC, Rosella LC, Foisy J, McGeer A, Crowcroft N. The social determinants of

5. Slusser M. The logic in ecological: I. The logic of analysis. Am J Public Health. health and pandemic H1H1 2009 influenza severity. Am J Public Health. 2012;102(8):511994;84(5):825-829. doi:doi/10.2105/AJPH.84.5.825

6. Texier G, Farouh M, Pellegrin L, et al. Outbreak definition by change point analysis: A tool for public health decision? BMC Med Inform Decis Mak. 2016;16(1):1-12. doi:10.1186/s12911-016-0271-X

7. Mitjà O, Clotet B. Use of antiviral drugs to reduce COVID-19 transmission. Lancet Glob Heal. 2020;(20):1-2. doi:10.1016/S2214-109X(20)30114-5 http://www.cepii.fr/institutions/EN/ipd.asp. Published 2016. Accessed March 19, 2020.

9. Madhav N, Oppenheim B, Gallivan M, Mulembakani P, Rubin E, Wolfe N. Pandemics: Washington, DC: World Bank Group; 2017:315-345.

10. Imports of Goods and Services (Current US\$). The World Bank. https://data.worldbank.org/indicator/NE.IMP.GNFS.CD. Published 2017. Accessed March $19,2020$.

11. Population Density (People per sq. $\mathrm{km}$ of Land Area). The World Bank. https://data.worldbank.org/indicator/EN.POP.DNST. Published 2018. Accessed March 19, 2020. 
medRxiv preprint doi: https://doi.org/10.1101/2020.03.30.20047589; this version posted April 1, 2020. The copyright holder for this preprint (which was not certified by peer review) is the author/funder, who has granted medRxiv a license to display the preprint in perpetuity. It is made available under a CC-BY-ND 4.0 International license .

Cross-National Variation in COVID-19 Outbreaks

Messner, W.

242 12. Irvin RA, Stansbury J. Citizen Participation in Decision Making: Is It Worth the effort?

243 Public Adm Rev. 2004;64(1):55-65. doi:10.1111/j.1540-6210.2004.00346.x

244 13. Beierle TC, Konisky DM. What are we gaining from stakeholder involvement?

245 Observations from environmental planning in the Great Lakes. Environ Plan C Gov Policy.

$246 \quad 2001 ; 19(4): 515-527$. doi:10.1068/c5s

247 14. Santiso C. IMPROVING FISCAL GOVERNANCE AND CURBING CORRUPTION :

248 HOW RELEVANT ARE AUTONOMOUS AUDIT AGENCIES ? 2006;7(2):97-108.

249 15. Primary Completion Rate, Total (\% of Relevant Age Group). The World Bank. 250 https://data.worldbank.org/indicator/SE.PRM.CMPT.ZS. Published 2018. Accessed March 19, 2020.

16. Sorveglianza Integrata COVID-19 in Italia. Ordinanza n. 640, 21 Mar 2020. Istituto 253 Superiore di

Sanità. Published 2020. Accessed March 22, 2020.

17. Country Comparison: Median

Age. CIA World Factbook. https://www.cia.gov/library/publications/the-world-factbook/fields/rawdata_343.txt. Published 2020. Accessed March 19, 2020.

18. Hofstede G. Culture's Consequences: Comparing Values, Behaviors, Institutions, and Organizations across Nations. 2nd ed. Thousand Oaks, CA: Sage; 2001.

19. Fincher CL, Thornhill R, Murray DR, Schaller M. Pathogen prevalence predicts human cross-cultural variability in individualism/collectivism. Proc $R$ Soc $B$ Biol Sci. 2008;275(1640):1279-1285. doi:10.1098/rspb.2008.0094

20. Borg MA, Camilleri L, Waisfisz B. Understanding the epidemiology of MRSA in Europe: Do we need to think outside the box? J Hosp Infect. 2012;81(4):251-256. doi:10.1016/j.jhin.2012.05.001

22. Winterich KP, Zhang Y. Accepting Inequality Deters Responsibility: How Power Distance Decreases Charitable Behavior. J Consum Res. 2014;41(2):274-293. doi:10.1086/675927 
medRxiv preprint doi: https://doi.org/10.1101/2020.03.30.20047589; this version posted April 1, 2020. The copyright holder for this preprint (which was not certified by peer review) is the author/funder, who has granted medRxiv a license to display the preprint in perpetuity. It is made available under a CC-BY-ND 4.0 International license.

Cross-National Variation in COVID-19 Outbreaks

Messner, W. Epidemiologic Studies. Epidemiology. 2016;06(2):1-9. doi:10.4172/2161-1165.1000227

274 24. Frank KA. Impact of a confounding variable on a regression coefficient. Sociol Methods Res. 2000;29(2):147-194. doi:10.1177/0049124100029002001

276 25. Frank KA, Maroulis SJ, Duong MQ, Kelcey BM. What would it take to change an inference? Using Rubin's causal model to interpret the robustness of causal inferences. Educ Eval Policy Anal. 2013;35(4):437-460. doi:10.3102/0162373713493129

279 26. Solomon T, Lewthwaite P, Perera D, Cardosa MJ, McMinn P, Ooi MH. Virology, epidemiology, pathogenesis, and control of enterovirus 71. Lancet Infect Dis. 2010;10(11):778-790. doi:10.1016/S1473-3099(10)70194-8

27. Joshi H, Lenhart S, Albright K, Gipson K. Modeling the effect of information campaigns on the HIV epidemic in Uganda. Math Biosci Eng. 2008;5(4):757-770. doi:10.3934/mbe.2008.5.757

28. Ferguson JK. Preventing healthcare-associated infection: risks, healthcare systems and behaviour. Intern Med J. 2009;39(9):574-581. doi:10.1111/j.1445-5994.2009.02004.x

29. Bao Y, Sun Y, Meng S, Shi J, Lu L. 2019-nCoV epidemic: address mental health care to 289 empower society. Lancet. 2020;395(10224):e37-e38. doi:10.1016/S0140-6736(20)30309-3 
medRxiv preprint doi: $h$ ttps://doi.org/10.1101/2020.03.30.20047589; this version posted April 1, 2020. The copyright holder for this preprint

(which was not certified by peer review) is the author/funder, who has granted medRxiv a license to display the preprint in perpetuity. It is made available under a CC-BY-ND 4.0 International license.

Cross-National Variation in COVID-19 Outbreaks

Messner, W.

290 Table 1: Relative growth rate of COVID-19 and contextual variables

\begin{tabular}{|c|c|c|c|c|c|c|c|c|c|c|c|c|c|}
\hline Country & GROWTH $\mathrm{P}$ & POLINS & DISCOV & IMPORT & DNSITY & PARPOP $\mathrm{F}$ & FREEINF C & CORRUP & EDUCAT $\quad A$ & AGEMED & INDLSM & POWDIS I & INDULG \\
\hline Afghanistan & 0.159 & 2.250 & 4.025 & 9.153 & 4.042 & 2.667 & 3.500 & 0.000 & 3.842 & 19.5 & & & \\
\hline Albania & 0.260 & 2.500 & 4.234 & 6.070 & 4.650 & 2.000 & 4.000 & 1.000 & 4.560 & 34.3 & & & \\
\hline Algeria & 0.202 & 2.250 & 4.043 & 55.604 & 2.875 & 2.333 & 3.500 & 0.500 & 4.464 & 28.9 & 20 & 77 & 78.000 \\
\hline Argentina & 0.281 & 3.000 & 4.159 & 89.853 & 2.789 & 2.333 & 4.000 & 1.250 & 4.601 & 32.4 & 46 & 49 & 61.830 \\
\hline Armenia & 0.294 & 2.750 & 4.111 & 5.706 & 4.641 & 1.000 & 3.000 & 0.750 & 4.560 & 36.6 & & & \\
\hline Australia & 0.081 & 4.000 & 3.219 & 273.699 & 1.178 & 4.000 & 4.000 & 3.750 & & 37.5 & 90 & 38 & 71.429 \\
\hline Austria & 0.299 & 3.750 & 4.043 & 211.711 & 4.675 & 2.667 & 4.000 & 3.250 & 4.596 & 44.5 & 55 & 11 & 62.723 \\
\hline Azerbaijan & 0.162 & 1.750 & 4.094 & 17.104 & 4.790 & 2.333 & 2.000 & 0.750 & 4.555 & 32.6 & & & \\
\hline Bahrain & 0.150 & 2.750 & 4.007 & 23.876 & 7.610 & 1.667 & 3.000 & & 4.573 & 32.9 & 38 & 80 & 34.000 \\
\hline Bangladesh & 0.139 & 3.000 & 4.234 & 50.614 & 7.123 & 1.667 & 3.000 & & 4.022 & 27.9 & 20 & 80 & 19.643 \\
\hline Belarus & 0.199 & 1.000 & 4.078 & 36.436 & 3.844 & 1.000 & 2.500 & 2.000 & 4.612 & 40.9 & & & \\
\hline Belgium & 0.191 & 4.000 & 3.555 & 407.020 & 5.933 & 3.000 & 4.000 & 4.000 & 4.297 & 41.6 & 75 & 65 & 56.696 \\
\hline Bosnia and Herzegovina & 0.246 & 3.000 & 4.190 & 10.200 & 4.173 & 1.000 & 4.000 & 1.000 & & 43.3 & & & \\
\hline Brazil & 0.307 & 3.750 & 4.043 & 237.622 & 3.221 & 2.667 & 4.000 & 1.000 & 4.692 & 33.2 & 38 & 69 & 59.152 \\
\hline Brunei & 0.366 & & 4.248 & 4.318 & 4.399 & 0.333 & 1.000 & 2.500 & 4.643 & 31.1 & & & \\
\hline Bulgaria & 0.336 & 3.250 & 4.220 & 37.120 & 4.170 & 3.000 & 4.000 & 0.750 & 4.581 & 43.7 & 30 & 70 & 15.848 \\
\hline Cambodia & 0.047 & 1.250 & 3.332 & 14.219 & 4.522 & 1.667 & 4.000 & 0.500 & 4.336 & 26.4 & & & \\
\hline Cameroon & 0.205 & 1.000 & 4.205 & 7.895 & 3.977 & 1.000 & 3.000 & 0.000 & 4.091 & 18.5 & & & \\
\hline Canada & 0.099 & 4.000 & 3.258 & 554.657 & 1.405 & 4.000 & 4.000 & 3.500 & 4.567 & 41.8 & 80 & 39 & 68.304 \\
\hline Chile & 0.334 & 4.000 & 4.159 & 75.394 & 3.226 & 2.667 & 4.000 & 2.500 & 4.576 & 35.5 & 23 & 63 & 68.000 \\
\hline China & 0.116 & & & 2208.504 & 5.000 & 0.667 & 2.000 & 0.250 & 4.585 & 38.4 & 20 & 80 & 23.661 \\
\hline Colombia & 0.405 & 2.750 & 4.205 & $\quad 62.882$ & 3.801 & 2.333 & 4.000 & 1.500 & 4.529 & 31.2 & 13 & 67 & 83.036 \\
\hline Costa Rica & 0.301 & 3.750 & 4.205 & 19.195 & 4.584 & 2.667 & 4.000 & 2.250 & 4.481 & 32.6 & 15 & 35 & \\
\hline Croatia & 0.163 & 4.000 & 4.043 & 27.333 & 4.292 & 2.333 & 4.000 & 1.750 & 4.546 & 43.9 & 33 & 73 & 33.259 \\
\hline Cyprus & 0.342 & 3.750 & 4.248 & 16.614 & 4.858 & 4.000 & 4.000 & 2.500 & 4.512 & 37.9 & & & \\
\hline Czech Republic & 0.302 & 3.750 & 4.127 & 155.896 & 4.924 & 2.000 & 4.000 & 2.250 & 4.608 & 43.3 & 58 & 57 & 29.464 \\
\hline Denmark & 0.356 & 4.000 & 4.060 & 158.589 & 4.928 & 3.333 & 4.000 & 4.000 & 4.597 & 42.0 & 74 & 18 & 69.643 \\
\hline Dominican Republic & 0.194 & 2.750 & 4.127 & 21.234 & 5.394 & 1.000 & 4.000 & 0.500 & 4.472 & 27.9 & & & \\
\hline Ecuador & 0.205 & 2.750 & 4.111 & 22.516 & 4.231 & 3.667 & 4.000 & 0.250 & 4.576 & 28.8 & & 78 & \\
\hline Egypt & 0.191 & 2.750 & 3.829 & 68.983 & 4.594 & 2.000 & 3.500 & 0.750 & 4.464 & 24.1 & 38 & 80 & 34.000 \\
\hline Estonia & 0.307 & 4.000 & 4.078 & 19.253 & 3.414 & 2.333 & 4.000 & 3.500 & 4.583 & 43.7 & 60 & 40 & 16.295 \\
\hline Finland & 0.127 & & 3.401 & 95.590 & 2.899 & 4.000 & 4.000 & 3.250 & 4.602 & 42.8 & 63 & 33 & 57.366 \\
\hline France & 0.151 & 4.000 & 3.219 & 824.460 & 4.807 & 3.333 & 4.000 & 3.500 & 4.594 & 41.7 & 71 & 68 & 47.768 \\
\hline Georgia & 0.167 & 3.250 & 4.060 & 9.342 & 4.179 & 2.333 & 4.000 & 2.750 & 4.648 & 38.6 & & & \\
\hline Germany & 0.153 & 4.000 & 3.332 & 1473.522 & 5.470 & 4.000 & 4.000 & 4.000 & 4.605 & 47.8 & 67 & 35 & 40.402 \\
\hline Greece & 0.258 & 4.000 & 4.060 & 69.070 & 4.422 & 3.000 & 4.000 & 0.500 & 4.576 & 45.3 & 35 & 60 & 49.554 \\
\hline Hungary & 0.240 & 3.750 & 4.174 & 113.002 & 4.681 & 2.333 & 4.000 & 1.000 & 4.561 & 43.6 & 80 & 46 & 31.473 \\
\hline Iceland & 0.252 & 4.000 & 4.094 & 10.291 & 1.260 & 4.000 & 4.000 & 3.500 & 4.596 & 37.1 & & & \\
\hline India & 0.094 & 4.000 & 3.401 & 583.124 & 6.120 & 3.333 & 3.500 & 1.250 & 4.428 & 28.7 & 48 & 77 & 26.116 \\
\hline Indonesia & 0.314 & 3.500 & 4.127 & 194.699 & 4.996 & 2.667 & 3.500 & 0.750 & 4.536 & 31.1 & 14 & 78 & 37.723 \\
\hline Iran & 0.278 & 2.750 & 3.932 & 108.230 & 3.916 & 2.333 & 2.500 & 1.000 & 4.530 & 31.7 & 41 & 58 & 40.402 \\
\hline Iraq & 0.166 & 2.750 & 4.025 & 69.661 & 4.483 & 3.000 & 3.000 & 0.000 & 4.145 & 21.2 & & & \\
\hline Ireland & 0.331 & 4.000 & 4.111 & 331.338 & 4.255 & 2.333 & 4.000 & 2.500 & 4.601 & 37.8 & 70 & 28 & 64.955 \\
\hline Israel & 0.239 & 4.000 & 3.970 & 97.221 & 6.017 & 4.000 & 4.000 & 3.250 & 4.653 & 30.4 & 54 & 13 & \\
\hline Italy & 0.245 & 3.750 & 3.434 & 545.247 & 5.325 & 2.333 & 4.000 & 1.500 & 4.615 & 46.5 & 76 & 50 & 29.688 \\
\hline Japan & 0.113 & 4.000 & 2.708 & 818.383 & 5.850 & 3.000 & 4.000 & 2.750 & & 48.6 & 46 & 54 & 41.741 \\
\hline Jordan & 0.253 & 2.750 & 4.143 & 22.941 & 4.720 & 1.000 & 3.000 & 1.750 & 4.490 & 23.5 & 38 & 80 & 34.000 \\
\hline Kuwait & 0.102 & 3.750 & 4.007 & 56.304 & 5.447 & 2.667 & 3.500 & 1.250 & 4.544 & 29.7 & & & \\
\hline Latvia & 0.300 & 4.000 & 4.143 & 18.714 & 3.433 & 1.000 & 4.000 & 1.750 & 4.578 & 44.4 & 70 & 44 & 12.946 \\
\hline Lebanon & 0.205 & 2.500 & 3.970 & 25.972 & 6.507 & 1.333 & 4.000 & 0.250 & & 33.7 & 38 & 80 & 34.000 \\
\hline Lithuania & 0.201 & 4.000 & 4.078 & 33.925 & 3.796 & 2.667 & 4.000 & 3.000 & 4.612 & 44.5 & 60 & 42 & 15.625 \\
\hline Luxembourg & 0.339 & 4.000 & 4.111 & 116.816 & 5.522 & 2.667 & 4.000 & 4.000 & 4.406 & 39.5 & 60 & 40 & 56.027 \\
\hline Macedonia & 0.200 & 1.750 & 4.060 & 7.802 & 4.414 & 3.000 & 4.000 & 1.000 & 4.540 & 39.0 & & & \\
\hline Malaysia & 0.081 & 3.000 & 3.219 & 201.498 & 4.564 & 2.667 & 3.000 & 1.250 & 4.573 & 29.2 & 26 & 100 & 57.143 \\
\hline Malta & 0.265 & 3.750 & 4.220 & 16.414 & 7.321 & 4.000 & 4.000 & 2.000 & 4.626 & 42.3 & 59 & 56 & 65.625 \\
\hline Mexico & 0.206 & 2.750 & 4.094 & 457.356 & 4.173 & 2.333 & 4.000 & 0.000 & 4.570 & 29.3 & 30 & 81 & 97.321 \\
\hline Moldova & 0.353 & 2.250 & 4.220 & 5.274 & 4.816 & 2.333 & 3.000 & 1.250 & 4.539 & 37.7 & & & \\
\hline Mongolia & 0.183 & 3.500 & 4.248 & 6.562 & 0.713 & 2.000 & 4.000 & 1.250 & 4.520 & 29.8 & & & \\
\hline Morocco & 0.272 & 2.500 & 4.143 & 51.304 & 4.391 & 2.000 & 3.500 & 1.000 & 4.186 & 29.1 & 46 & 70 & 25.446 \\
\hline Netherlands & 0.330 & 4.000 & 4.078 & 604.197 & 6.237 & 3.667 & 4.000 & 3.500 & 4.569 & 42.8 & 80 & 38 & 68.304 \\
\hline New Zealand & 0.162 & 4.000 & 4.078 & 54.053 & 2.921 & 3.000 & 4.000 & 4.000 & & 37.2 & 79 & 22 & 74.554 \\
\hline Nigeria & 0.094 & 2.750 & 4.078 & 49.508 & 5.371 & 2.667 & 4.000 & 0.000 & 4.374 & 18.6 & 20 & 77 & 78.000 \\
\hline Norway & 0.291 & 4.000 & 4.060 & 130.798 & 2.678 & 4.000 & 4.000 & 4.000 & 4.598 & 39.5 & 69 & 31 & 55.134 \\
\hline Oman & 0.098 & 2.750 & 4.025 & 34.960 & 2.748 & 1.333 & 1.500 & 3.000 & 4.358 & 26.2 & 38 & 80 & 34.000 \\
\hline Pakistan & 0.235 & 3.000 & 4.060 & 53.590 & 5.618 & 1.667 & 3.500 & 0.250 & 4.132 & 22.0 & 14 & 55 & 0.000 \\
\hline Panama & 0.375 & 3.000 & 4.248 & 28.219 & 4.029 & 2.333 & 4.000 & 0.250 & 4.495 & 30.1 & 11 & 95 & \\
\hline Paraguay & 0.213 & 2.750 & 4.220 & 12.599 & 2.863 & 2.333 & 4.000 & 1.250 & 4.366 & 29.7 & & & \\
\hline Peru & 0.382 & 3.750 & 4.205 & 48.096 & 3.219 & 1.667 & 4.000 & 1.000 & 4.551 & 29.1 & 16 & 64 & 46.205 \\
\hline Philippines & 0.086 & 3.750 & 3.401 & 128.185 & 5.880 & 2.000 & 4.000 & 1.000 & 4.524 & 24.1 & 32 & 94 & 41.964 \\
\hline Poland & 0.379 & 3.000 & 4.159 & 264.007 & 4.821 & 2.667 & 3.500 & 2.250 & 4.573 & 41.9 & 60 & 68 & 29.241 \\
\hline Portugal & 0.333 & 4.000 & 4.143 & 92.111 & 4.721 & 3.000 & 4.000 & 2.500 & & 44.6 & 27 & 63 & 33.259 \\
\hline
\end{tabular}


medRxiv preprint doi: https://doi.org/10.1101/2020.03.30.20047589; this version posted April 1, 2020. The copyright holder for this preprint (which was not certified by peer review) is the author/funder, who has granted medRxiv a license to display the preprint in perpetuity. It is made available under a CC-BY-ND 4.0 International license .

Cross-National Variation in COVID-19 Outbreaks

Messner, W.

\begin{tabular}{|c|c|c|c|c|c|c|c|c|c|c|c|c|c|}
\hline Country & GROWTH & POLINS & DISCOV & IMPORT & DNSITY & PARPOP & FREEINF & CORRUP & EDUCAT & AGEMED & INDLSM & POWDIS I & INDULG \\
\hline Qatar & 0.325 & & 4.111 & 62.193 & $\begin{array}{l}5.479 \\
\end{array}$ & $\begin{array}{l}\quad 0.667 \\
\end{array}$ & 3.000 & $3 \quad 3.000$ & $0 \quad 4.434$ & $\begin{array}{ll}4 & 33.7\end{array}$ & $\begin{array}{ll}7 \quad 38 \\
\end{array}$ & 380 & 34.000 \\
\hline Romania & 0.266 & 3.000 & 4.060 & 92.287 & 4.438 & 2.000 & 4.000 & 0.250 & 4.540 & 42.5 & 30 & 90 & 19.866 \\
\hline Russia & 0.084 & 2.500 & 3.466 & 326.913 & 2.177 & 2.333 & 2.500 & 1.500 & 4.556 & 40.3 & 39 & 93 & 19.866 \\
\hline Saudi Arabia & 0.331 & & 4.143 & 202.046 & 2.752 & 1.333 & 3.000 & 2.000 & 4.632 & 30.8 & 38 & 80 & 34.000 \\
\hline Senegal & 0.208 & 4.000 & 4.143 & 7.505 & 4.411 & 2.000 & 3.500 & 2.250 & 3.843 & 19.4 & 20 & 77 & 78.000 \\
\hline Serbia & 0.405 & 2.500 & 4.205 & 25.207 & 4.380 & 2.000 & 4.000 & 0.750 & 4.604 & 43.4 & 25 & 86 & 28.125 \\
\hline Singapore & 0.069 & 3.500 & 3.178 & 495.467 & 8.981 & 3.000 & 3.000 & 4.000 & 4.600 & 35.6 & 20 & 74 & 45.536 \\
\hline Slovakia & 0.342 & 4.000 & 4.205 & 88.496 & 4.730 & 3.333 & 4.000 & 1.000 & 4.567 & 41.8 & & & \\
\hline Slovenia & 0.329 & 4.000 & 4.174 & 35.996 & 4.631 & 2.667 & 4.000 & 2.500 & 4.575 & 44.9 & 27 & 71 & 47.545 \\
\hline South Africa & 0.363 & 3.750 & 4.190 & 99.085 & 3.863 & 3.333 & 4.000 & 1.500 & 4.453 & 28.0 & 65 & 49 & \\
\hline South Korea & 0.173 & 4.000 & 2.996 & 576.913 & 6.272 & 3.333 & 4.000 & 3.500 & 4.620 & 43.2 & 18 & 60 & 29.464 \\
\hline Spain & 0.227 & 3.750 & 3.466 & 413.731 & 4.538 & 2.667 & 4.000 & 0.750 & 4.607 & 43.9 & 51 & 57 & 43.527 \\
\hline Sri Lanka & 0.049 & 2.250 & 3.332 & 25.403 & 5.845 & 2.333 & 3.000 & 1.000 & 4.574 & 33.7 & & & \\
\hline Sweden & 0.180 & 4.000 & 3.466 & 222.841 & 3.219 & 4.000 & 4.000 & 3.750 & 4.603 & 41.1 & 71 & 31 & 77.679 \\
\hline Switzerland & 0.330 & 4.000 & 4.043 & 370.406 & 5.373 & 4.000 & 4.000 & 2.750 & 4.347 & 42.7 & 68 & 34 & 66.071 \\
\hline Taiwan & 0.059 & 3.750 & 3.045 & & & 4.000 & 4.000 & 2.250 & & 42.3 & 17 & 58 & 49.107 \\
\hline Thailand & 0.063 & & 2.565 & 247.430 & 4.912 & 2.333 & 4.000 & 1.500 & 4.459 & 39.0 & 20 & 64 & 45.089 \\
\hline Togo & 0.055 & 2.000 & 4.205 & 2.103 & 4.977 & 1.667 & 4.000 & 1.000 & 4.063 & 20.0 & & & \\
\hline Tunisia & 0.259 & 3.000 & 4.143 & 22.671 & 4.310 & 3.000 & 3.500 & 0.750 & 4.437 & 32.7 & 38 & 80 & 34.000 \\
\hline Turkey & 0.790 & 2.500 & 4.277 & 249.702 & 4.672 & 1.667 & 2.500 & 1.250 & 4.572 & 32.2 & 37 & 66 & 49.107 \\
\hline Ukraine & 0.210 & 2.500 & 4.159 & 62.494 & 4.344 & 3.333 & 3.000 & 1.250 & 4.599 & 41.2 & & & \\
\hline United Arab Emirates & 0.076 & & 3.296 & 290.783 & 4.910 & 0.333 & 3.000 & 2.500 & 4.449 & 38.4 & 38 & 80 & 34.000 \\
\hline United Kingdom & 0.150 & 4.000 & 3.434 & 841.969 & 5.616 & 4.000 & 4.000 & 4.000 & 4.615 & 40.6 & 89 & 35 & 69.420 \\
\hline United States & 0.138 & 3.750 & 3.045 & 2932.062 & 3.577 & 4.000 & 4.000 & 4.000 & 4.593 & 38.5 & 91 & 40 & 68.080 \\
\hline Vietnam & 0.052 & 2.000 & 3.178 & 221.075 & 5.731 & 2.333 & 3.000 & 0.250 & 4.629 & 31.9 & 20 & 70 & 35.491 \\
\hline
\end{tabular}

GROWTH: Outbreak's relative growth rate; POLINS: Functioning of political institutions $(0=$ widespread irregularities to $4=$ perfectly fair $)$; DISCOV: Time gap till discovery of first case, logged; IMPORT: Import volume (2017, in bn USD); DNSITY: Population density (2018), logged; PARPOP: Participation in political institutions (0 = very low to 4 = strong participation); FREEINF: Access to foreign information $(0=$ no to $4=$ total freedom); CORRUP: Corruption $(0=$ high to $4=$ very low level); EDUCAT: Performance of education system (average of years 2000 to 2018), logged; AGEMED: Median age; INDLSM: Individualism (0 = strongly collectivistic to $100=$ strongly individualistic); POWDIS: Power distance ( $0=$ low to $100=$ high); INDULG: Indulgence $(0=$ typically restraint to $100=$ typically indulgent).

293 Table 2: Regression results

\begin{tabular}{|c|c|c|c|c|c|c|c|c|}
\hline \multirow[b]{2}{*}{ Constant } & beta & Beta & Std. err. & \multirow[b]{2}{*}{-8.738} & VIF & \multicolumn{2}{|r|}{$\begin{array}{l}\text { Confound } \\
\text { threshold }\end{array}$} & $\begin{array}{l}\text { Impact } \\
\text { threshold }\end{array}$ \\
\hline & -1.153583 & & 0.132025 & & $5.57 \mathrm{E}-12$ & & & \\
\hline POLINS & 0.121066 & 1.098561 & 0.011473 & 10.552 & $7.86 \mathrm{E}-15$ & 3.999 & 81.151 & 0.696 \\
\hline DISCOV & 0.247635 & 1.167458 & 0.017465 & 14.179 & $5.15 E-20$ & 2.502 & 85.972 & 0.801 \\
\hline IMPORT & 0.000166 & 0.528302 & 0.000025 & 6.510 & $2.39 \mathrm{E}-08$ & 2.430 & 70.046 & 0.482 \\
\hline DNSITY & -0.007607 & -0.095227 & 0.004624 & -1.645 & 0.105634 & 1.236 & 17.288 & 0.030 \\
\hline PARPOP & -0.061203 & -0.552946 & 0.009286 & -6.591 & $1.76 \mathrm{E}-08$ & 2.597 & 69.823 & 0.479 \\
\hline FREEINF & -0.070824 & -0.569313 & 0.010113 & -7.003 & 3.73E-09 & 2.438 & 71.600 & 0.508 \\
\hline CORRUP & -0.062390 & -0.647649 & 0.009035 & -6.905 & 5.39E-09 & 3.246 & 71.197 & 0.501 \\
\hline EDUCAT & 0.110094 & 0.333678 & 0.025384 & 4.337 & 0.000062 & 2.184 & 54.141 & 0.279 \\
\hline AGEMED & 0.005623 & 0.460424 & 0.001188 & 4.731 & 0.000016 & 3.495 & 57.978 & 0.318 \\
\hline INDLSM & -0.001668 & -0.319459 & 0.000451 & -3.696 & 0.000507 & 2.757 & 46.222 & 0.210 \\
\hline POWDIS & -0.001911 & -0.326253 & 0.000472 & -4.052 & 0.000161 & 2.392 & 50.874 & 0.248 \\
\hline INDULG & 0.001203 & 0.230221 & 0.000349 & 3.450 & 0.001084 & 1.643 & 42.299 & 0.181 \\
\hline
\end{tabular}

POLINS: Functioning of political institutions ( $0=$ widespread irregularities to $4=$ perfectly fair); DISCOV: Time gap till discovery of first case, logged; IMPORT: Import volume (2017, in bn USD); DNSITY: Population density (2018), logged; PARPOP: Participation in political institutions $(0=$ very low to $4=$ strong participation); FREEINF: Access to foreign information $(0=$ no to $4=$ total freedom); CORRUP: Corruption $(0=$ high to $4=$ very low level); EDUCAT: Performance of education system (average of years 2000 to 2018), logged; AGEMED: Median age; INDLSM: Individualism ( $0=$ strongly collectivistic to $100=$ strongly individualistic); POWDIS: Power distance (0 = low to $100=$ high); INDULG: Indulgence ( 0 = typically restraint to $100=$ typically indulgent). 
medRxiv preprint doi: https://doi.org/10.1101/2020.03.30.20047589; this version posted April 1, 2020. The copyright holder for this preprint (which was not certified by peer review) is the author/funder, who has granted medRxiv a license to display the preprint in perpetuity. It is made available under a CC-BY-ND 4.0 International license .

Cross-National Variation in COVID-19 Outbreaks

Messner, W.

Figure 1: Association between time lag of COVID-19 outbreak and growth rate

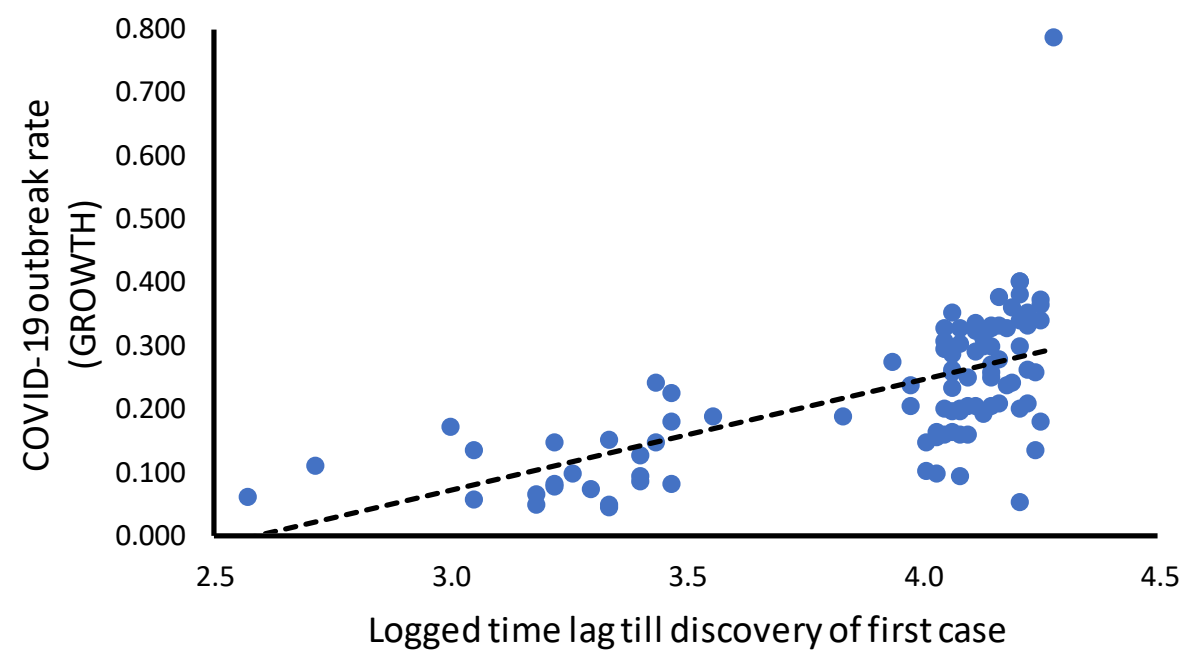

302

(DISCOV)

Figure 2: Association between import volume and time lag of COVID-19 outbreak

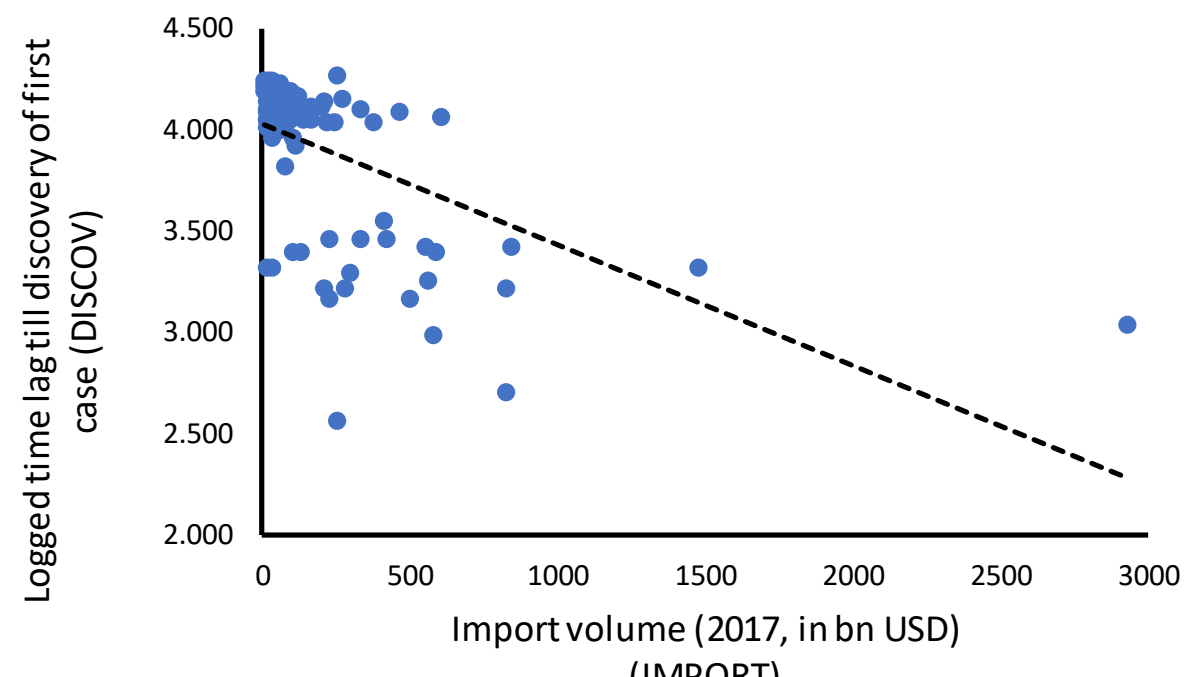

